\title{
Analisis Pemasaran Buah Naga (Hylocereus Undatus) Di Kabupaten Banyuwangi
}

\author{
Syamsul Hadi \\ Program Studi Agribisnis Fakultas Pertanian \\ Universitas Muhammadiyah Jember
}

\begin{abstract}
Dragon fruit to be one of the flagship products Banyuwangi, but some patterns running inefficient marketing chains with an indication of some farmers receive farmer's share is less than 50\% and most marketing agencies involved received benefits irrational. Least efficient marketing dragon fruit is determined by the length of the short marketing channels that lead further on the high and low cost marketing functions that must be removed. The objectives of this study were: 1) Tracing patterns dragon fruit marketing chains are awakened in Banyuwangi, and 2) to analyze margins, marketing efficiency, and elasticity of price transmission dragon fruit marketing. The type and method used in this research is descriptive and survey conducted in 2016 - 2017 some of the districts in Banyuwangi and Jember with sampling techniques through incidental and snowbolling sampling and data collection techniques in depth interviews and observations of the 32 respondents merchants, The results of this study concluded that: 1) Marketing of dragon fruits in the study area is formed of three patterns of chain marketing, where marketing agencies involved include, Small traders, merchant wholesalers, traders wholesalers, and retailers, each of which performs the function of different marketing, and 2) the results of the analysis of marketing margins dragon fruit showed that the pattern of the third chain is the most efficient marketing chain and patterns I chain most inefficient as indicated by the farmer's share of respectively $55.45 \%$ and $45 \%$. The marketing price transmission elasticity Et dragon fruit $(0.4)<1$ or run inefficiently.
\end{abstract}

Keywords: Pattern chain marketing, marketing margin and marketing efficiency

\section{Pendahuluan}

Tanaman buah naga (dragon fruit) yang awalnya dikenal sebagai tanaman hias ini sudah cukup lama dikenal masyarakat Taiwan, Vietnam, maupun Thailand. Terlebih saat diketahui bahwa buahnya dapat dikonsumsi, semakin banyak yang mengenalnya. Bagi masyarakat di negara tersebut, usaha budidaya tanaman buah naga terus dilakukan karena sangat menguntungkan (Kristanto, 2008). Buah naga sekarang mulai tersedia di toko buah dan pasar swalayan dan sejumlah perkebunan melirik komoditas ini karena budidayanya mudah dan prospek ke depan cerah dibanding buah lainnya. Tetapi Indonesia masih tercatat sebagai pengimpor buah 
naga cukup besar hingga mencapai 200-400 ton/tahun asal Thailand dan Vietnam sebagai akibat tingginya permintaan buah naga yang diyakini berkhasiat mujarab untuk berbagai penyakit dan bermanfaat sebagai bahan baku di bidang industri pengolahan makanan, minuman, kosmetik serta produk kesehatan (Anonim, 2008).

Hingga saat ini kebutuhan akan buah naga Indonesia cukup besar dan bukan hanya pasar lokal saja. Peluang ekspor masih terbuka lebar untuk buah naga ini, namun kebutuhan yang besar tersebut belum mampu dipenuhi oleh produksi dalam negeri karena Indonesia dalam kondisi yang cukup sulit memenuhi peluang pasar dan adanya hal-hal yang berhubungan dengan iklim investasi yang cenderung lesu. Kabupaten Banyuwangi secara geografis merupakan daerah yang subur dan memiliki potensi yang besar bagi peningkatan pengembangan produk pertanian, karena hampir semua komoditas pertanian khususnya tanaman pangan dan hortikultura dapat tumbuh dan berkembang. Dukungan kekayaan sumber daya alam yang melimpah serta permintaan pasar yang tinggi menempatkan komoditas hortikultura sebagai produk bernilai ekonomi tinggi, sehingga usaha hortikultura menjadi sumber pendapatan petani dan pelaku usaha lainnya di daerah Provinsi Jawa Timur termasuk Kabupaten Banyuwangi.

Produksi buah naga di Kabupaten Banyuwangi menunjukkan peningkatan yang pesat dala beberapa tahun terakhir, dimana pada tahun 2014 produksinya mencapai 28.819 ton dengan luas lahan 1.152 hektar meningkat dibanding tahun 2013 yang hanya 16.631 ton dengan luas lahan hanya 678 hektar. Sementara produktivitas buah naga di Banyuwangi mengalami peningkatan dari $245 \mathrm{kw} / \mathrm{ha}$ tahun 2013 menjadi $250 \mathrm{kw} / \mathrm{ha}$ tahun 2014. Pemasaran buah naga Banyuwangi telah merambah pasar luar Jawa seperti Kalimantan, Makasar dan Maluku. Bahkan Kecamatan Bangorejo saja menyumbang 39 persen dari total produksi buah naga di Banyuwangi atau setara 11.000 ribu ton/ha dengan luas lahannya sendiri mencapai 449 ha. Oleh karena itu, Kabupaten Banyuwangi saat ini terkenal sebagai lumbung buah naga tertinggi di Jawa Timur (Dinas Pertanian, Perkebunan dan Kehutanan Kabupaten Banyuwangi, 2015).

Fenomena menarik yang tengah berkembang di daerah Kabupaten Banyuwangi khususnya bagian selatan adalah petani yang memiliki lahan sawah 
atau tegalan terbatas menerapkan sistem usahatani multiple cropping dwi komoditas, yaitu tanaman buah naga sebagai tanaman pokok, dan komoditas kedelai menjadi tanaman sela. Selain itu, sebagian besar petani mengusahakan lahannya dengan sistem usahatani monoculture, yaitu buah naga saja khususnya yang mengusahakannya di lahan pekarangan rumah yang pada umumnya adalah buah naga varitas putih dan merah, Harga jual produk buah baga merah lebih mahal dibandingkan yang putih dengan jumlah permintaan yang relatif seimbang. Kecuali pada usahatani jeruk manis, sebagian besar petani buah naga masih menggunakan teknik dan peralatan usahatani yang cukup sederhana dan akses pemasarannya masih terbatas. Walaupun demikian sebagian kecil petani buah naga yang berskala usaha menengah dan luas, teknologi (bahan dan alat) yang digunakan tergolong moderen karena modal yang dimiliki sangat memadai dengan jangkauan pemasarannya luas. Diantaranya adalah penggunaan lampu listrik yang tersebar di areal tanam buah naga guna merangsang pembuahan lebih cepat daripada tanpa pemberian lampu listrik, sehingga dalam satu tahun biasanya panen buahnya hanya satu kali, maka dengan penggunaan lampu bisa panen dua kali.

Kenaikan jumlah penawaran yang dilakukan produsen berhubungan dengan mening-katnya permintaan konsumen terhadap buah jeruk itu sendiri. Selain karena tuntutan permintaan pasar, keuntungan yang diperoleh produsen sangat menentukan semangatnya dalam bekerja untuk lebih meningkatkan penawarannya terhadap buah naga. Panjangnya rantai pemasaran dari petani di daerah sentra produksi yang terdistribusi ke daerah Kabupaten Banyuwangi di tingkat lokal hingga ke luar daerah seperti Kabupaten Jember, Situbondo, Bondowoso, Lumajang, dan Probolinggo hingga ke luar Pulau Jawa, membawa implikasi pada pola saluran dan margin serta efisiensi pemasaran buah naga. Pola saluran pemasaran dan tingkat efisiennya akan menentukan tingkat kesesuaian harga baik pada tingkat petani produsen maupun konsumen. Kondisi ini juga dapat berpengaruh terhadap tingkat motivasi dalam mengelola usahatani buah naga. Margin pemasaran yang tinggi dengan tingkat rasio keuntungan dan biaya yang tidak proporsional dan iirrasional dimana harga di tingkat petani yang relatif rendah, mendorong petani kurang intensif dalam mengelola usahataninya. 
Berdasarkan uraian di atas, maka tujuan penelitian ini meliputi: 1) Menelusuri pola saluran pemasaran buah naga yang terbangun di Kabupaten Banyuwangi, dan 2) Menganalisis margin, efisiensi pemasaran, dan elastisitas transmisi harga pemasaran buah naga tersebut. Oleh karena itu, maka dapat dirumuskan hiputesis sebagai berikut:1) Diduga bahwa share margin of farmer pada saluran pemasaran buah naga $>50 \%$ atau berjalan efisien, dan 2) Diduga bahwa pemasaran komoditas buah naga di Kabupaten Banyuwangi memiliki elastisitas transmisi harga Et $>1$ atau berjalan belum efisien.

\section{Metode Penelitian}

\section{Jenis dan Metode Penelitian serta Teknik Pengambilan Sampel}

Jenis penelitian ini adalah penelitian deskriptif, yaitu penelitian yang bertujuan untuk menggambarkan fenomena secara sitematis, faktual dan akurat mengenai fakta-fakta, sifat-sifat dan hubungan antar fenomena yang terjadi pada masa sekarang dan metode penelitian yang digunakan dalam penelitian ini adalah metode survei (Nazir, 1985). Pengambilan sampel dilakukan secara insidental sampling dan snowbolling sampling, Maksud Sampling Insidental adalah teknik penentuan sampel berdasarkan kebetulan, yaitu siapa saja yang secara kebetulan/insidental bertemu dengan peneliti dapat digunakan sebagai sampel, bila dipandang orang yang kebetulan ditemui itu cocok dengan sumber data. Adapun Snowball Sampling adalah teknik penentuan sampel yang mula-mula jumlahnya kecil, kemudian membesar ibarat bola salju yang menggelinding yang lama-lama menjadi besar. Dalam penentuan sampel, pertama-tama dipilih satu atau dua orang, tetapi dengan dua orang ini belum merasa lengkap terhadap data yang diberikan, maka peneliti mencari orang lain yang dipandang lebih tahu dan dapat melengkapi data yang diberikan dua orang sebelumnya (Sugiyono, 2014).

Sementara itu, jumlah sampel pedagang buah naga yang terambil sebanyak 32 orang responden yang tersebar pada beberapa wilayah kecamatan sampel di daerah Kabupaten Banyuwangi, dan Jember baik yang berlokasi di pasar induk maupun kecamatan dan desa. Sampel pedagang keliling (pengecer) berjumlah 8 orang, pedagang pengecer di pasar tradisional (Pasar induk dan kecamatan/desa) sebanyak 8 orang, pedagang kecil di daerah lokasi sentra produksi buah naga 
sebanyak 6 orang, pedagang pengumpul (pengepul sebanyak 6 orang, dan pedagang besar antar daerah sebanyak 4 orang. Adapun teknik pengumpulan data dilakukan dengan wawancara terhadap responden melalui teknik depth intervew maupun observasi guna melengkapinya dengan teknik inventory.

\section{Lokasi Penelitian}

Penelitian ini telah dilakukan di Kecamatan Purwoharjo, Tegaldlimo, Pesanggaran, Siliragung, Bangorejo, Muncar, dan Cluring secara purposive sampling atas pertimbangan bahwa beberapa wilayah kecamatan tersebut merupakan sentra produksi buah naga di Kabupaten Banyuwangi. Artinya keberadaan responden seperti pedagang kecil, pengepul, pedagang besar bahkan pedagang keliling (pengecer) dapat dipastikan berada di wilayah kecamatan sampel, sehingga lokasi tersebut menjadi salah satu pertimbangan peneliti untuk dijadikan daerah ampel. Selain itu, wilayah kecamatan Genteng, Gambiran, Glenmore, Kalibaru, Srono, Rogojampi, Kota, Singujuruh, Sempu, dan Wongsorejo juga menjadi kecamatan sampel termasuk beberapa wilayah kecamatan di Kabupaten Jember seperti Silo, Mayang, Kalisat, Sumbersari dan Pasar Induk.

\section{Analisa Data}

Guna menjawab tujuan pertama, mama dilakukan identifikasi pola saluran pemasaran yang terbangun atas proses pemasaran komoditas buah naga di Kabupaten Banyuwangi, maka dilakukan penelurusan dari petani sampai kepada konsumen akhir dan selanjutnya dibuat rantai pemasaran (marketing chain) tiap pola saluran pemasaran tersebut melalui analisa deskriptif kualitatif dan diinterpretasi untuk selanjutnya ditarik kesimpulan secara inferensial. Sementara untuk menjawab tujuan kedua, maka dilakukan analisis marjin pemasaran, efisiensi dan elastisitas transmisi harga. Margin pemasaran merupakan perbedaan harga ditingkat konsumen (harga yang terjadi karena perpotongan kurva permintaan primer dengan kurva penawaran turunan) dengan harga di tingkat produsen (harga yang terjadi karena perpotongan kurva penawaran primer dengan permintaan turunan) (Hastuti dan Rahim, 2007).

Rasionalitas dapat diketahui dengan mebandingkan antara tingkat 
keuntungan dengan biaya yang dikeluarkan oleh lembaga pemasaran selama proses transaksi jual beli buah naga berlangsung ( Rasio $=\pi /$ Sbi ). Selain itu, lebih ditegaskan bahwa untuk mengetahui besarnya distribusi keuntungan tiap saluran pemasaran dapat diukur dengan rumus:

$$
\text { DK }=\frac{[(\pi / C) \text { terendah })]}{[((\pi / C) \text { tertinggi })]}
$$

Keterangan: DK $=$ Distribusi keuntungan, $\pi=$ Keuntungan pemasaran, $\mathrm{C}=$ Biaya pemasaran dengan kriteria keputusan: Jika $\mathrm{DK} \geq 0,5$ berarti distribusi keuntungan antar lembaga pemasaran adil, dan Jika DK $<0,5$ berarti distribusi keuntungan antar lembaga pemasaran tidak adil.

Selanjutnya untuk mengetahui saluran pemasaran yang mana memiliki tingkat efisiensi tertinggi, maka digunakan analisis matematis dengan rumus sebagai berikut (Gultom, 1996 dalam Putra Bisuk, 2009):

$$
\text { Ep }=\text { - }
$$

Semakin kecil nilai Ep, maka semakin efisien pemasaran pada saluran Pemasaran tersebut, dan dapat dikatakan efisien jika Ep $<50 \%$. Untuk mengetahui saluran mana yang paling efisien, maka setiap saluran pemasaran dibandingkan nilai Ep atas sejumlah lembaga pemasaran yang terlibat. Selanjutnya Gultom (1996) dalam Putra Bisuk (2009) juga menyatakan bahwa pada umumnya suatu sistem tataniaga untuk (sebagian) produk hasil pertanian dapat dikatakan sudah efisien bila share margin petani berada di atas 50\%. Adapun bagian harga yang diterima petani (farmer's share) merupakan perbandingan harga yang diterima oleh petani dengan harga di tingkat lembaga pemasaran yang dinyatakan dalam persentase. Farmer's share dimaksud dirumuskan sebagai berikut: $\mathrm{Fs}=\mathrm{P}_{\mathrm{f}} / \mathrm{P}_{\mathrm{r}} \times 100 \%$.

Efisisensi pemasaran merupakan tolak ukur atas produktivitas proses pemasaran dengan membandingkan sumberdaya yang digunakan terhadap keluaran yang dihasilkan selama berlangsungnya proses pemasaran (Downey dan Steven, 1994 dalam Hastuti dan Rahim, 2007). Dari sudut pandang marketing mix, efisiensi pemasaran menurut Downey dan Erickson (1992) dalam Hastuti dan Rahim (2007) dapat dilihat dari masing-masing elemen, yaitu: 
1. Efisiensi produk merupakan usaha untuk menghasilkan suatu produk melalui penghematan harga serta penyederhanaan prosedur teknis produksi guna keuntungan maksimum.

2. Efisiensi distribusi dinyatakan sebagai produk dari produsen menuju ke pasar sasaran melalui saluran distribusi yang pendek atau berusaha menghilangkan satu atau lebuh mata rantai pemasaran yang panjang di mana distribusi produk berlangsung dengan tindakan penghematan biaya dan waktu.

3. Efisiensi harga yang menguntungkan pihak produsen dan konsumen diikuti dengan keuntungan yang layak diambil oleh setiap mata rantai pemasaran sehingga harga yang terjadi di tingkat petani tidak berbeda jauh dengan harga yang terjadi di tingkat konsumen.

4. Efisiensi promosi mencerminkan penghematan biaya dalam melaksanakan pemberitahuan di pasar sasaran mengenai produk yang tepat, meliputi penjualan perorangan atau missal dan promosi penjualan.

Selanjutnya menurut Azzaino (1982) dalam Masyoefi (1994) juga menjelaskan tentang elastisitas harga transmisi $(\eta)$ dimana definisinya adalah sebagai persentase peruba-han harga eceran terhadap persentase perubahan harga ditingkat petani produsen atau analisis elastisitas transmisi harga atau nisbah perubahan nilai dari harga konsumen dengan peruba-han harga di tingkat produsen yang dapat dihitung melalui formulasi rumus sebagai berikut:

Dimana

$$
\eta=\frac{\% \Delta \operatorname{Pr}}{\% \Delta \operatorname{Pf}}=\frac{\partial \operatorname{Pr} \cdot \operatorname{Pf}}{\partial \operatorname{Pf} \cdot \operatorname{Pr}}
$$

$\eta=$ elastisitas harga transmisi

$\operatorname{Pr}=$ harga di tingkat konsumen

$\mathrm{Pf}=$ harga di tingkat petani produsen

$\partial \mathrm{Pr}=$ perubahan harga di tingkat konsumen

$\partial \mathrm{Pf}=$ perubahan harga di tingkat produsen

Harga mempunyai hubungan linier, di mana Pf merupakan fungsi dari Pr yang secara matematis dirumuskan sebagai : $\operatorname{Pf}=a+b \operatorname{Pr}$ atau $\operatorname{Pf}=a+\operatorname{Pr} \eta$. Dari persamaan tersebut dapat diperoleh bahwa $\mathrm{E}_{\mathrm{t}}=\delta \operatorname{Pr} / \delta \mathrm{Pf} . \operatorname{Pr} / \operatorname{Pf}$, di mana: $\mathrm{E}_{\mathrm{t}}=$ Elastisitas transmisi harga, $\delta=$ Diferensiasi atau turunan, $\mathrm{Pf}=$ Harga rata-rata 
di tingkat petani (produsen), Pr = Harga rata-rata di tingkat konsumen, $\mathrm{a}=$ Konstanta atau titik potong, dan $b=$ Koefisien regresi. Oleh karena kriteria keputusannya adalah sebagai berikut (Azzaino, 1982 dalam Masyoefi, 1994):

a) Jika Et $=1$, maka perubahan harga sebesar $1 \%$ di tingkat pengecer akan mengakibatkan perubahan harga sebesar $1 \%$ di tingkat petani dan merupakan pasar persaingan sempurna, dan sistem tataniaga yang terjadi sudah efisien,

b) Jika Et $<1$, maka Apabila elastisitas transmisi harga lebih kecil dari satu (Et $<$ 1) dapat diartikan bahwa perubahan harga sebesar $1 \%$ di tingkat pengecer akan mengakibatkan perubahan harga kurang dari $1 \%$ di tingkat petani dan bentuk pasar mengarah ke Monopsoni/Oligopsoni dan pemasaran berlangsung tidak efisien, dan

c) Jika Et $>1$, berarti Apabila elastisitas transmisi harga lebih besar dari satu (Et $>1$ ), maka perubahan harga sebesar $1 \%$ di tingkat pengecer akan mengakibatkan perubahan harga lebih besar dari $1 \%$ di tingkat petani dan bentuk pasarnya mengarah ke Monopoli atau pemasaran belum efisien.

\section{Hasil Dan Pembahasan}

\section{Saluran Pemasaran Buah Naga}

Panjang pendeknyanya suatu saluran pemasaran akan ditentukan oleh banyaknya pedaganh perantara (medleman) yang dilalui oleh suatu barang dan jasa. Saluran distribusi yang terlalu panjang menyebabkan makin banyak rantai yang ikut dalam kegiatan pemasaran dan berimplikasi pada luasnya jangkauan pada konsumen akhir, namun harganya relatif mahal. Sebaliknya saluran distribusi yang terlalu pendek kurang efektif untuk penyebarlu-asan, tetapi karena mata rantai pemasaran lebih pendek maka biaya produksi dapat ditekan sehingga harga ke konsumen dapat lebih rendah.Oleh karena itu, panjang pendeknya saluran pemasaran akan menentukan tinggi rendahnya tingkat efisiensi pemasarannya.

Saluran pemasaran buah naga asal Kabupaten Banyuwangi yang terbangun terdiri dari tiga macam pola saluran pemasaran. Kondisi ini berbeda dengan pola pemasaran buah naga di Kabupaten Jember dalam sebuah artikel dengan judul Pemasaran Agribisnis pada Komoditas Buah 
Naga di Kabupaten Jember tahun 2013. Bahwa terdapat dua saluran pemasaran yang ada pada komoditas buah naga di Kabupaten Jember, yakni (Irmawati, 2013): 1) Produsen (petani) $\rightarrow$ tengkulak $\rightarrow$ pedagang pengumpul $\rightarrow$ pengecer $\rightarrow$ konsumen, dan 2 ) produsen $\rightarrow$ pedagang pengecer $\rightarrow$ konsumen. Hal ini disebabkan karena pemasaran komoditas buah naga asal Kabupaten Jember masing tergolong baru sehingga jumlah produksi dan luas panennya masih relatif terbatas. Sedangkan buah naga asal Kabupaten Banyuwangi sudah berskala besar dan menjadi salah satu produk unggulan dengan pasar ekspor. Banyak pola sluran buah naga yang terbangun di kabupaten Banyuwangi sejalan dengan hasil penelitian Nuryasin, Prasmatiwi, dan Santoso (2014) di Kecamatan Sragi Kabupaten Lampung Selatan yang mengungkapkan bahwa saluran pemasaran yang terbentuk ada 3 (tiga) saluran pemasaran. Berikut ini akan digambarkan tiga pola saluran pemasaran buah naga dari Kabupaten Banyuwangi.

1)

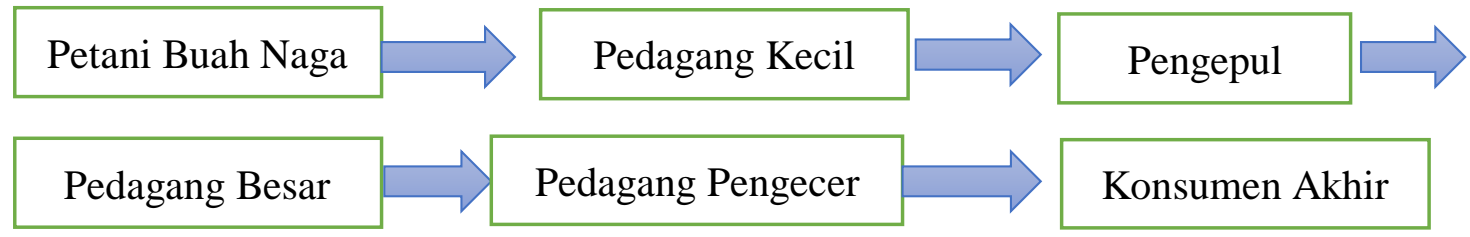

2)

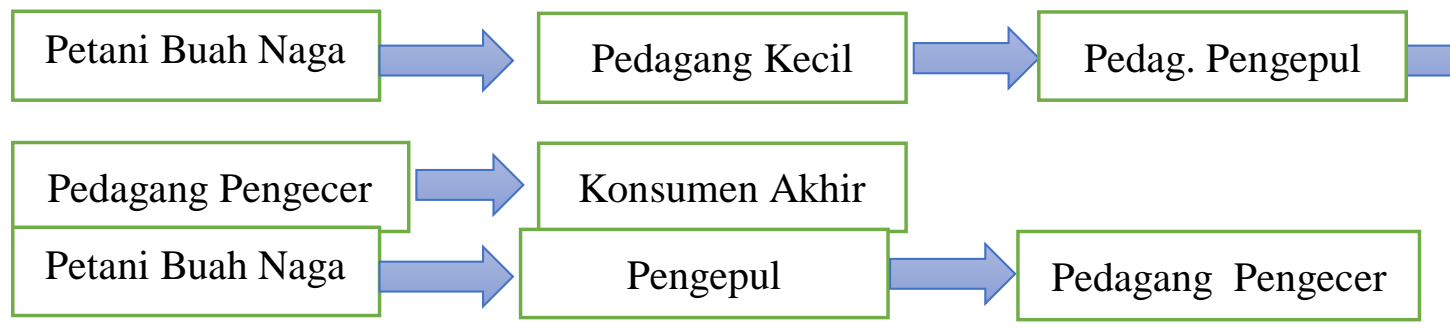

\section{Konsumen Akhir}

Masing-masing lembaga pemasaran tersebut melakukan fungsi-fungsi pemasaran yang berbeda-beda, yaitu sebagai berikut: Petani buah naga: melakukan fungsi penjualan, Pedagang kecil: melakukan fungsi pembelian-pemanenan, penjualan, pengangkutan, pembiayaan, dan informasi pasar, Pedagang pengepul: melakukan 
fungsi pembelian, penjualan, pengangkutan, sortasi, standarisasi, penyimpanan, pembiayaan dan Informasi pasar, Pedagang pedagang besar: melakukan fungsi pembelian, penjualan, pengangkutan, sortasi, standarisas-grading, penyimpanan, penanggungan resiko, pembiayaan dan Informasi pasar, dan Pengecer: melakukan fungsi pembelian, penjualan, penyimpanan, pengangkutan, sortasi, pembiayaan, dan informasi pasar.

\section{Margin dan Efisiensi Pemasaran Buah Naga serta Elastisitas Transmisi Harga Pola Saluran Pemasaran Pertama}

Tabel 3.1 menunjukkan bahwa saluran I pada pemasaran buah naga di daerah penelitian berjalan dengan tidak efisien yang diindikasikan bahwa Farmer's share besarnya kurang dari $50 \%$. Lembaga pemasaran yang terlibat dalam pemasaran buah naga ini yang paling banyak menerima keuntungan adalah pengepul meskipun biaya pemasaran yang dikeluarkan untuk melakukan fungsifungsi pemasaran bukan paling rendah dibandingkan dengan lainnya. Hal ini disebabkan selisih harga beli dan jual sangat tinggi dibandingkan dengan biaya pemasarannya. Pengepul hanya melakukan fungsi pembelian, penjualan, pengangkutan, penyimpanan dan biaya restribusi. Adapun pedagang besar antar daerah bila diukur dari sisi biaya pemasaran untuk melakukan berbagai fungsi pemasaran justru memperoleh nilai rasio keuntungan-biaya pemasaran paling rendah. Kondisi distribusi keuntungan pada Saluran I ini masih belum adil karena nilainya hanya 0,43 atau $<0,5$.

Tabel 3.1

Analisis Marjin Pemasaran Buah Naga pada Pola Saluran Pemasaran Pertama di Kabupaten Banyuwangi Bagian Selatan, Tahun 2017

\begin{tabular}{|c|c|c|c|c|c|c|c|c|}
\hline No & $\begin{array}{c}\text { Jenis } \\
\text { Lembaga } \\
\text { Pemasaran } \\
\text { Buah Naga }\end{array}$ & $\begin{array}{c}\text { Harga } \\
\text { Beli /Kg }\end{array}$ & $\begin{array}{c}\text { Harg } \\
\text { a } \\
\text { Jual } \\
\text { /Kg }\end{array}$ & $\begin{array}{c}\text { Biaya } \\
\text { Pemasar } \\
\text { an/ Kg }\end{array}$ & $\begin{array}{l}\text { Keuntung } \\
\text { an } / \mathbf{K g}\end{array}$ & $\begin{array}{c}\text { Share } \\
\text { Margin } \\
\text { untuk } \\
\text { Petani } \\
(\%) \\
\text { (Pf/Pr) x } \\
\text { 100\% }\end{array}$ & $\begin{array}{c}\text { Efisiensi } \\
\text { Pemasara } \\
\text { n [ } \\
\text { (Biaya } \\
\text { Pemasara } \\
\text { n : Nilai } \\
\text { Penjualan } \\
\text { ) x 100\% } \\
\text { ] }\end{array}$ & $\begin{array}{c}\text { Rasio } \\
\text { (Untun } \\
\text { g/ } \\
\text { Biaya) }\end{array}$ \\
\hline 1 & 2 & 3 & 4 & 5 & 6 & 7 & 8 & 9 \\
\hline \multicolumn{3}{|c|}{$\begin{array}{c}\text { Rata-rata Harga Tingkat } \\
\text { Petani (Pf) }\end{array}$} & $\begin{array}{c}4,50 \\
0\end{array}$ & & & 45.00 & & \\
\hline 1 & Pedagang & 4,500 & & & 520 & & & 1.08 \\
\hline
\end{tabular}




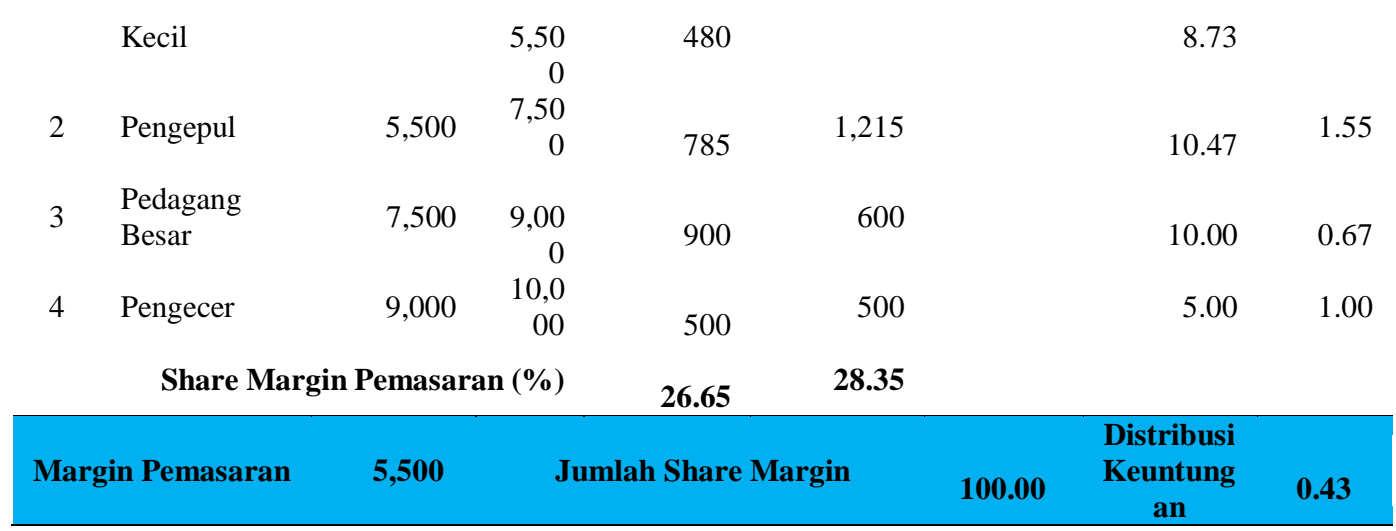

Sumber: Data Primer Diolah, 2017

Tabel 3.1 di atas juga memberikan gambaran bahwa pengepul memiliki rasio keuntungan-biaya pemasaran paling tinggi dibandingkan lembaga pemasaran lainnya, sedangkan pengecer memiliki tingkat efisiensi pemasaran paling tinggi karena antara biaya pemasaran dan harga jual produk pada konsumen akhir besarnya sama. Pada konsisi ini pihak petani dan konsumen akhir menjadi korbannya karena petani harus menerima harga yang relatif rendah dan konsumen harus membayar seluruh biaya pada proses distribusi produk dengan harga yang tinggi hingga sampai kepada tangannya. Oleh karena itu, Saluran pemasaran I belum memberikan tingkat kepuasan dikehendaki semua pihak, karena pola saluran ini merupakan rantai terpanjang dibandingkan dua pola saluran lainnya. Diketahui bahwa pada Saluran I ini pedagang besar mendistribusikan buah naga dari daerah penelitian ke daerah Kabupaten Jember, Bondowoso, Lumajang dan Situbondo.

\section{Pola Saluran Pemasaran Kedua}

Pada saluran II sebagimana yang tampak dalam Tabel 3.2. memberikan gambaran bahwa nilai Farmer's share (50\%) lebih tinggi daripada Saluran I yang menunjukkah bahwa pola saluran II berjalan secara efisien. Adapun pengecer memproleh rasio keuntungan-biaya pemasaran paling tinggi (2) dan justru pengepul memperolehnya paling rendah. Hal ini disebabkan pengepul paling banyak melakukan fungsi pemasaran seperti fungsi pembelian, penjualan, penyimpanan, pengangkutan, standarisasi-grading, sortasi, dan informasi pasar. Tabel 3.2 menunjukkan bahwa distribusi keuntungan (DK) terhadap semua lembaga pemasaran yang terlibat sangat tidak adil karena nilai DK hanya $0,38(<0,50)$, 
dimana pengecer menerima keuntungan lebih tinggi dengan biaya paling rendah. Sementara itu, tingkat keuntungan pedagang kecil paling tinggi, namun biayanya juga lebih tinggi daripada yang dikeluarkan pengecer. Diketahui bahwa pada Saluran II ini pengepul buah naga didatangi pengecer untuk didistribusikan ke luar wilayah kecamatan sentra produksi buah naga, seperti ke wilayah kecamatan kota, Wongsorejo, Rogojampi, Sempu, dan Kalibaru.

Tabel 3.2.

Analisis Marjin Pemasaran Buah Naga pada Pola Saluran Pemasaran Kedua di Kabupaten Banyuwangi Bagian Selatan, Tahun 2017

\begin{tabular}{|c|c|c|c|c|c|c|c|c|}
\hline No & $\begin{array}{c}\text { Jenis } \\
\text { Lembaga } \\
\text { Pemasaran } \\
\text { Buah Naga }\end{array}$ & $\begin{array}{c}\text { Harga } \\
\text { Beli /Kg }\end{array}$ & $\begin{array}{c}\text { Harga } \\
\text { Jual } \\
\text { /Kg }\end{array}$ & $\begin{array}{c}\text { Biaya } \\
\text { Pemasaran/ } \\
\text { Kg }\end{array}$ & $\begin{array}{c}\text { Keuntungan } \\
/ \mathrm{Kg}\end{array}$ & $\begin{array}{c}\text { Share Margin } \\
\text { untuk Petani } \\
(\%)(P f / P r) x \\
100 \%\end{array}$ & $\begin{array}{c}\text { Efisiensi } \\
\text { Pemasaran } \\
\text { [ (Biaya } \\
\text { Pemasaran : } \\
\text { Nilai } \\
\text { Penjualan) } x \\
100 \% \text { ] } \\
\end{array}$ & $\begin{array}{c}\text { Rasio } \\
\text { (Untung/ } \\
\text { Biaya) }\end{array}$ \\
\hline 1 & 2 & 3 & 4 & 5 & 6 & 7 & 8 & 9 \\
\hline \multicolumn{3}{|c|}{$\begin{array}{c}\text { Rata-rata Harga Tingkat } \\
\text { Petani (Pf) }\end{array}$} & 5,000 & & & 50.00 & & \\
\hline 1 & $\begin{array}{l}\text { Pedagang } \\
\text { Kecil }\end{array}$ & 5,000 & 7,000 & 700 & 1,300 & & 10.00 & 1.86 \\
\hline 2 & Pengepul & 7,000 & 8,500 & 850 & 650 & & 10.00 & 0.76 \\
\hline \multirow[t]{2}{*}{3} & Pengecer & 8,500 & 10,000 & 500 & 1,000 & & \multirow[t]{2}{*}{5.00} & \multirow[t]{2}{*}{2.00} \\
\hline & \multicolumn{3}{|c|}{ Share Margin Pemasaran (\%) } & 20.50 & 29.50 & & & \\
\hline \multicolumn{2}{|c|}{$\begin{array}{c}\text { Margin } \\
\text { Pemasaran (MP) }\end{array}$} & 5,000 & & \multicolumn{2}{|c|}{ Jumlah Share Margin } & 100.00 & $\begin{array}{l}\text { Distribusi } \\
\text { Keuntungan } \\
\text { (DK) }\end{array}$ & 0.38 \\
\hline
\end{tabular}

Sumber: Data Primer Diolah, 2017

\section{Pola Saluran Pemasaran Ketiga}

Tabel 3.3 menunjukkan bahwa Saluran III merupakan pola saluran pemasaran buah naga di daerah penelitan yang paling efisien disamping rantain pemasarannya terpendek dibandingan pola saluran lainnya. Hal ini dibuktikan bahwa nilai farmer's share mencapai angka di atas 50\% yang berarti bahwa harga yang diterima oleh petani $(\mathrm{Rp} 6000 / \mathrm{kg})$ lebih tinggi dari nilai marjin pemasarannya (MP) (Rp 5000/Kg). Namun demikian DK pada saluran III ini berjalan sangat tidak adil karena nilainya $(0,23)<0,50$, dimana pengecer menerima keuntungan paling tinggi dengan biaya pemasaran paling rendah dibandingkan dengan pedagang pengepul. Oleh karena itu, tingkat efisiensi pemasaran yang dicapai pengecer $(2,73)$ 
lebih tinggi daripada yang dicapai pengepul $(8,13)$. Fungsi pemasaran yang dilakukan oleh pengepul jauh lebih variatif dibandingkan pengecer, dimana pengecer hanya melakukan fungsi pembelian, penjualan dan pengangkutan serta restribusi pasar. Jangkauan pendistribu-sian produk buah naga ini cukup terbatas pada wilayah sekitar wilayah sentra produksi buah naga di daerah penelitian, yaitu Pasar tradisional di Genteng, Glenmore, dan Sempu.

Tabel 3.3.

Analisis Marjin Pemasaran Buah Naga pada Pola Saluran Pemasaran Ketiga di Kabupaten Banyuwangi Bagian Selatan, Tahun 2017

\begin{tabular}{|c|c|c|c|c|c|c|c|c|}
\hline No & $\begin{array}{c}\text { Jenis } \\
\text { Lembaga } \\
\text { Pemasara } \\
\text { n Buah } \\
\text { Naga }\end{array}$ & $\begin{array}{c}\text { Harga } \\
\text { Beli /Kg }\end{array}$ & $\begin{array}{c}\text { Harga } \\
\text { Jual } \\
\text { /Kg }\end{array}$ & $\begin{array}{c}\text { Biaya } \\
\text { Pemasara } \\
\text { n/Kg }\end{array}$ & $\begin{array}{c}\text { Keuntu } \\
\text {-ngan } \\
\text { /Kg }\end{array}$ & $\begin{array}{c}\text { Share } \\
\text { Margin } \\
\text { untuk } \\
\text { Petani } \\
(\%) \\
\text { (Pf/Pr) x } \\
\text { 100\% }\end{array}$ & $\begin{array}{c}\text { Efisiensi } \\
\text { Pemasara } \\
\text { n [ } \\
\text { (Biaya } \\
\text { Pemasara } \\
\text { n : Nilai } \\
\text { Penjualan } \\
\text { ) x 100\% } \\
\text { ] } \\
\end{array}$ & $\begin{array}{c}\text { Rasio } \\
\text { (Untun } \\
\text { g/ } \\
\text { Biaya) }\end{array}$ \\
\hline 1 & 2 & 3 & 4 & 5 & 6 & 7 & 8 & 9 \\
\hline \multicolumn{3}{|c|}{$\begin{array}{c}\text { Rata-rata Harga Tingkat } \\
\text { Petani (Pf) }\end{array}$} & 6,000 & & & 54.55 & & \\
\hline 1 & Pengepul & 6,000 & 8,000 & 650 & 1,350 & & 8.13 & 2.08 \\
\hline 2 & Pengecer & 8,000 & 1,000 & 300 & 2,700 & & 2.73 & 9.00 \\
\hline \multicolumn{4}{|c|}{ Share Margin Pemasaran (\%) } & 8.64 & 36.82 & & & \\
\hline Pen & $\begin{array}{l}\text { Margin } \\
\text { asaran (MP) }\end{array}$ & 5,000 & \multicolumn{3}{|c|}{ Jumlah Share Margin } & 100.00 & $\begin{array}{l}\text { Distribusi } \\
\text { Keuntung } \\
\text { an (DK) }\end{array}$ & 0.23 \\
\hline
\end{tabular}

Sumber: Data Primer Diolah, 2017

Rata-rata ketiga pola saluran pemasaran buah naga di daerah penelitian berjalan efisien sebagaimana yang tampak pada Tabel 3.5 dimana rata-rata Farmer's share pada ketiga saluran pemasaran mencapai $50 \%$, kecuali pada pola slauran pemasaran I Farmer's share $<50 \%$. Hal ini sesuai dengan hasil penelitian Ningsih, Felani, dan Sakdiyah (2015) tentang Keragaan Usahatani dan Pemasaran Buah naga Organik di Kabupaten Pamekasan yang mengungkapkan bahwa kisaran (Acquirement) marjin pemasaran antara lembaga-lembaga pemasaran cenderung bervariasi dan timpang. Besarnya marjin pemasaran pada tengkulak (pedagang kecil) dan pedagang pengumpul masing-masing Rp 5.000/kg dan Rp 4.000/kg. 
Kondisi tersebut didukung oleh bahwa rata-rata distribuysi keuntungan (DK) pada semua pola saluran pemasaran belum menunjukkan sebaran keuntungan yang adil, karena nilai $\mathrm{DK}<0,50$ sebagaimana yang tampak pada Tabel 3.5.

Hasil penelitian ini agak berbeda dengan hasil penelitiannya Nuryasin, et al. (2014) di Kecamatan Sragi Kabupaten Lampung Selatan yang mengungkapkan ketiga pola saluran yang terbentuk seluruhnya berjalan belum (tidak) efisien, sedangkan pada penelitian ini salah satu pola saluran pemasaran buah naga (Pola Saluran I) berjalan tidak efisien dan dua pola lainnya berjalan efisien. Sementara rata-rata rasio keuntungan-biaya pemasaran masing-masing lembaga pemasaran yang terlibat tidak menunjukkan kondisi proporsional sebagaimana sama dengan hasil penelitian Nuryasin, et al. (2014), dimana pengecer memperoleh rasio yang paling tinggi diikuti oleh pengepul. Adapun pedagang pengepul dan pedagang besar mencapai rasio yang sama. Selanjutnya rata-rata pengecer mencapai tingkat efisiensi pemasaran paling tinggi dan pedagang besar antar daerah mencapai paling rendah akibat banyaknya fungsi pemasaran yang dilakukan.

Tabel 3.5 juga mengungkapkan bahwa elastisitas transmisi harga (Et) pemasaran buah naga dii daerah penelitian $<1$, tetapi bertanda positif. Namun sebelum mengangalisis elastisitas transmisi harga ini sebelumnya harus mencari koefisien regresi (b) dari variabel harga tingkat eceran (pr), karena harga mempunyai hubungan linier, dimana Pf merupakan fungsi dari Pr yang secara matematis dirumuskan sebagai: $\mathrm{Pf}=\mathrm{a}+\mathrm{b}$ Pr. Elastisitas harga dapat juga dicari dengan menggunakan logaritma dari fungsi (Azzaino, 1982) $: \operatorname{Pf}=\mathrm{a}+\operatorname{Pr} \mathrm{n}$, maka $\ln \mathrm{Pf}=\ln \mathrm{a}+\mathrm{n}$ ln Pr. Hasil analisis regresi melalui pendekatan model matematis tersebut menghasilkan nilai kofesien regresi pada variabel Pr sebesar 1,250 sebagaimana yang tampak pada tabel 3.4 di bawah ini 
Tabel 3.4. Hasil Analisis Regresi Terhadap Hubungan antara Harga Buah Naga tingkat Petani (Pf) dengan harga tingkat konsumen (Pr) pada Pemasaran Buah Naga di Kabupaten Banyuwangi Bagian Selatan, Th. 2017

\begin{tabular}{|c|c|c|c|c|c|c|}
\hline \multicolumn{7}{|c|}{ Coefficients $^{a}$} \\
\hline \multirow[b]{2}{*}{ Model } & & \multicolumn{2}{|c|}{ Unstandardized Coefficients } & \multicolumn{2}{|l|}{$\begin{array}{l}\text { Standardized } \\
\text { Coefficients }\end{array}$} & \multirow[b]{2}{*}{ Sig. } \\
\hline & & $\mathrm{B}$ & Std. Error & Beta & $\mathrm{t}$ & \\
\hline \multirow[t]{2}{*}{1} & (Constant) & -5250.000 & 7060.232 & & -.744 & .478 \\
\hline & $\mathrm{Pr}$ & 1.250 & .781 & .493 & 1.601 & .148 \\
\hline
\end{tabular}

Keterangan: Dependent Variable: Pf

Sumber: Data Primer Diolah, tahun 2017

Tabel 3.5.Analisis Marjin Pemasaran, Distribusi Keuntungan dan Elastisitas Transmisi Harga pada Rata-Rata Pola Saluran Pemasaran Buah Naga di Kabupaten Banyuwangi Bagian Selatan, Tahun 2017

\begin{tabular}{|c|c|c|c|c|c|c|c|c|}
\hline $\begin{array}{l}\mathbf{N} \\
\mathbf{O}\end{array}$ & $\begin{array}{c}\text { Jenis } \\
\text { Lembaga } \\
\text { Pemasaran } \\
\text { Buah Naga }\end{array}$ & $\begin{array}{l}\text { Ha } \\
\text { rga } \\
\text { Beli } \\
/ \text { Kg }\end{array}$ & $\begin{array}{l}\text { Har } \\
\text { ga } \\
\text { Jual } \\
\text { /Kg }\end{array}$ & $\begin{array}{c}\text { Biaya } \\
\text { Pemasar } \\
\text { an/Kg }\end{array}$ & $\begin{array}{c}\text { Keu } \\
\text { ntu- } \\
\text { ngan } \\
\text { /Kg }\end{array}$ & $\begin{array}{c}\text { Share } \\
\text { Margi } \\
\text { n } \\
\text { Pemas } \\
\text { aran } \\
(\%)\end{array}$ & 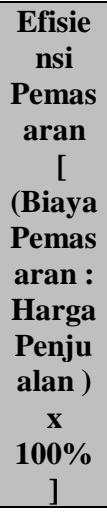 & $\operatorname{Rasio} \pi / C$ \\
\hline 1 & $\begin{array}{l}\text { Petani } \\
\text { Jeruk }\end{array}$ & & $\begin{array}{r}5,0 \\
00\end{array}$ & & & 50.00 & & \\
\hline 2 & $\begin{array}{l}\text { Pedagang } \\
\text { Kecil }\end{array}$ & $\begin{array}{r}5,0 \\
00\end{array}$ & $\begin{array}{r}6,0 \\
00\end{array}$ & 590 & 410 & 10.00 & 9.83 & 0.69 \\
\hline 3 & Pengepul & $\begin{array}{r}6,0 \\
00\end{array}$ & $\begin{array}{r}7,5 \\
00\end{array}$ & 718 & 783 & 15.00 & 9.57 & 1.09 \\
\hline 4 & $\begin{array}{l}\text { Pedagang } \\
\text { Besar antar } \\
\text { daerah }\end{array}$ & $\begin{array}{r}7,5 \\
00\end{array}$ & $\begin{array}{r}9,0 \\
00\end{array}$ & 900 & 600 & 15.00 & 10.00 & 0.67 \\
\hline 5 & Pengecer & $\begin{array}{r}9,0 \\
00 \\
\end{array}$ & $\begin{array}{c}10 \\
000\end{array}$ & 433 & 567 & 10.00 & 4.33 & 1.31 \\
\hline & $\begin{array}{c}\text { Margin } \\
\text { Pemasaran } \\
\quad(\mathbf{R p})\end{array}$ & $\begin{array}{l}\mathbf{5 , 0} \\
\mathbf{0 0}\end{array}$ & $\begin{array}{l}\text { Elastis } \\
\text { transn } \\
\text { harga } \\
(1 / b) \times\end{array}$ & $\begin{array}{l}\text { itas } \\
\text { iisi } \\
(\eta)=\end{array}$ & 0.40 & $\begin{array}{c}100.0 \\
0\end{array}$ & 8.43 & $\begin{array}{l}\text { Distribusi Keuntungan } \\
(\mathrm{DK})=\mathbf{0 . 3 5}\end{array}$ \\
\hline
\end{tabular}

Sumber: Data Primer Diolah, 2017

Tabel 3.5 juga menjelaskan elastisitas transmisi harga (Et) terhadap pola saluran pemasaran buah naga yang terbangun dimana nilain Et $<1$, yang dapat diartikan bahwa perubahan harga sebesar $1 \%$ di tingkat pengecer akan 
mengakibatkan perubahan harga kurang dari $1 \%$ di tingkat petani dan bentuk struktur pasar mengarah kepada pasar persaingan tidak sempurna. Adapun Et = 0,40 dapat diartikan bahwa apabila perubahan harga buah naga di tingkat konsumen akhir sebesar 1\%, maka akan mengakibatkan perubahan harga di tingkat petani naik hanya sebesar $0,40 \%$. Artinya sistem pemasaran yang terbentuk pada pola saluran pemasaran buah naga di daerah penelitian berjalan tidak efisien (Azzaino, 1982). Adapun struktur pasar yang terbentuk dalam hasil penelitian ini sama dengan hasil penelitian Nuryasin, et al. (2014) bahwa pasar oligopsoni, perilaku pasar mengarah pada penentuan harga (price maker) oleh pedagang, sedangkan petani sebagai penerima harga (price taker).

\section{KESIMPULAN}

1. Pola saluran pemasaran jeruk siam di daerah penelitian yang terbentuk lima macam rantai pemasaran, sedangkan pada pola saluran pemasaran buah naga membentuk tiga rantai pemasara. Saluran pemasaran dimaksud terdiri dari beberapa lembaga pemasaran yang terlbat yaitu meliputi, Petani, Pedagang kecil, Pedagang pengepul, Pedagang pedagang besar, dan Pengecer dimana masingmasing lembaga pemasaran tersebut melakukan fungsi pemasaran yang berbedabeda, dan

2. Hasil analisis marjin pemasaran jeruk siam menunjukkan bahwa pola saluran III adalah rantai pemasaran paling efisien dan pola saluran $\mathrm{V}$ paling tidak efisien, dimana diindikasikan dengan farmer's share masing-masing sebesar 59,09\% dan $40,91 \%$. Pola saluran pemasaran III melibatkan tiga lembaga pemasaran, yaitu petani, pedagang kecil, dan pengecer, sedangkan pola saluran V melibatkan tiga lembaga pemasaran yang meliputi petani, pengepul, dan pengecer. Selanjutnya pada hasil analisis marjin pemasaran buah naga menunjukkan bahwa pola saluran III adalah rantai pemasaran paling efisien dan pola saluran I paling tidak efisien, dimana diindikasikan dengan farmer's share masingmasing sebesar $55,45 \%$ dan $45 \%$. Pola saluran pemasaran III melibatkan tiga lembaga pemasaran, yaitu petani, pengepul, dan pengecer, sedangkan pola saluran I melibatkan lima lembaga pemasaran yang meliputi petani, pedagang kecil, pengepul, pedagang besar antar daerah dan pengecer. Adapun elastisitas 
transmisi harga kedua pemasaran komoditas tersebut besranya $\eta(E t)<1$, yaitu masing-masing sebesar - 1,57 dan 0,40 yang berarti keduanya berjalan tidak efisien. Perubahan harga sebesar $1 \%$ di tingkat pengecer akan mengakibatkan perubahan harga kurang dari $1 \%$ di tingkat petani dan bentuk struktur pasar mengarah kepada pasar persaingan tidak sempurna (Monopsoni atau monopolistik).

\section{UCAPAN TERIMA KASIH}

Penulis mengucapkan terima kasih yang tak terhingga kepada Lembaga Penelitian dan Pengabdian kepada Masyarakat - UM Jember yang telah mendukung terhadap penelitian ini dari berbagai macam kontribusi, sehingga penelitian ini dapat dilakukan dengan baik dan menghasilkan output berupa artikel ilmiah yang siap untuk dipublikasikan.

\section{DAFTAR PUSTAKA}

Anonim. 2008. Buah Naga. http://www.wikipedia.org/buah naga. Diakses pada tanggal 19 Nopember 2016.

Anonim, 2015. Dinas Pertanian, Kehutanan dan Perkebunan Kabupaten Banyuwangi. Jaringnews.com dan Tempo.com. Diakses pada tanggal 20 Nopember 2016.

Azziano, Z., 1982. Pengantar Tataniaga Pertanian. Departemen Pertanian. Ilmu-Ilmu Sosial Ekonomi Pertanian. Bogor: IPB Press.

Bisuk, P. 2009. Analisis Tataniaga Dan Elastisitas Transmisi Harga CPO Internasional Terhadap Harga TBS (Tandan Buah Segar) Kelapa Sawit. Studi Kasus Desa Mananti Kecamatan Sosa Kabupaten Padang Lawas. Skripsi USU. Diakses Pada Tanggal 17 Nopember 2016.

Dinas Pertanian, Kehutanan, dan Perkebunan Kabupaten Banyuwangi, 2015. Laporan Tahunan Dinas - SKPD Tahun 2015.

Hastuti D. R. dan Rahim A. 2007. Ekonomika Pertanian (pengantar, Teori, dan kasus). Jakarta: Penebar Swadaya. 
Irmawati, N., 2013. Pemasaran Agribisnis pada Komoditas Buah Naga di Kabupaten Jember. http://Mbem25. Just Wanna Share With Others. Diunduh pada tanggal 24 Oktober 2016

Kristanto, D. 2008. Buah Naga Pembudidayaan di Pot dan di Kebun. Jakarta: Penebar Swadaya.

Nazir, 1985. Metode Penelitian. Bandung: Grafika Indonesia.

Ningsih, K., Felani, H., Sakdiyah, H., 2015. Keragaan Usahatani dan Pemasaran Buah naga Organik di Kabupaten Pamekasan. Jurnal Agriekonomika. 4 (2): Halaman 169 - 184.

Nuryasin, M., Prasmatiwi, F.E., dan Santoso, H., 2014. Analisis Finansial dan Pemasaran Buah Naga di Kecamatan Sragi Kabupaten Lampung selatan. Skripsi. Fakultas Pertanian, Universitas Lampung. http://digilib.unila.ac.id/3000. Diakses Tanggal 25 Maret 2017.

Sugiyono, 2014. Metode Penelitian Kuantitatif Kualitatif dan $R \& D$. Bandung: Alfabeta. 